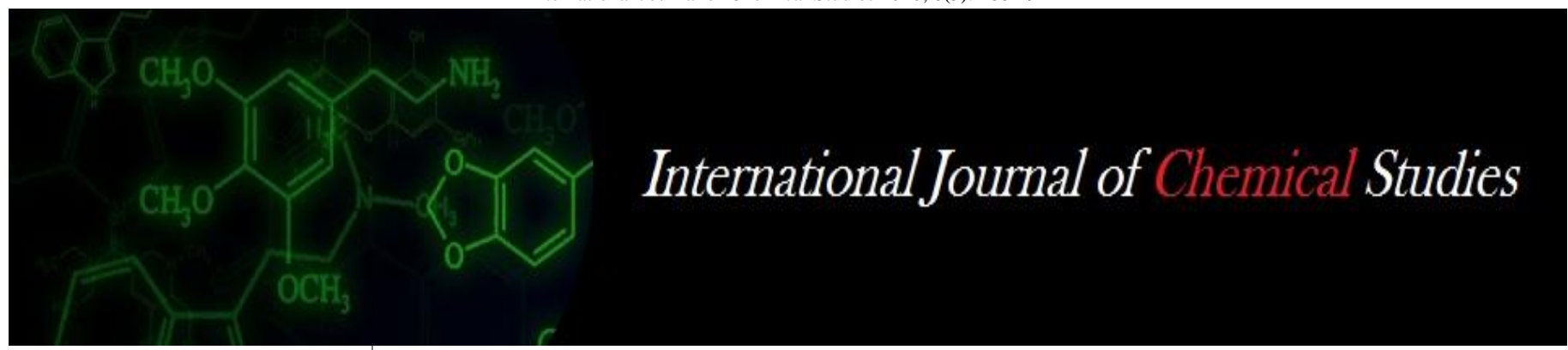

P-ISSN: 2349-8528

E-ISSN: 2321-4902

www.chemijournal.com

IJCS 2020; 8(5): 288-291

(C) 2020 IJCS

Received: 15-06-2020

Accepted: 07-08-2020

\section{Dilawar Helali}

Department of Fruit Science,

College of Horticulture,

Bagalkote, Karnataka, India

Sanjeevraddi G Reddi

Assistant Professor,

Department of Agronomy,

College of Horticulture,

Karnataka, India

Basavaraj P

Assistant Professor,

Department of Fruit Science,

College of Horticulture,

Bagalkote, Karnataka, India

\section{Mallikarjun A}

Assistant Professor of Crop

Physiology, Department of

Biotechnology and Crop

Improvement, College of

Horticulture, Bagalkote,

Karnataka, India

\section{Ramanagouda SH}

Assistant Professor,

Department of Entomology

College of Horticulture

Bagalkote, Karnataka, India

Siddanna $\mathbf{T}$

Assistant Professor of Fruit

Science, Horticulture Research

and Extension Centre,

Vijayapur, Tidagundi,

Karnataka, India

\section{Impact of different herbicides on weed control in grape (Vitis vinifera L.) $c v$. '2A clone'}

\author{
Dilawar Helali, Sanjeevraddi G Reddi, Basavaraj P, Mallikarjun A, \\ Ramanagouda SH and Siddanna T
}

DOI: https://doi.org/10.22271/chemi.2020.v8.i5d.10312

\begin{abstract}
A field experiment on "Impact of different herbicides on weed control in grape (Vitis vinifera L.) $c v$. 2A Clone" was carried out during October 2019 to March 2020 at fruit orchard, Main Horticultural Research and Extension Center (MHREC) Sector no 70, University of Horticultural Sciences, Udyanagiri, Bagalkote, to test the effect of various herbicides for controlling weeds in the vineyards under dry zone climate of north Karnataka. The trial was laid out in randomized complete block design (RCBD), having ten treatments with three replications. Lower number of total weeds $/ \mathrm{m}^{2} 4.67,9.00,16.00$ and $23.00 / \mathrm{m}^{2}$ at 30, 60, 90 and 120 days after spraying was recorded with $\mathrm{T}_{6}$-tank mix post-emergent application of oxyfluorfen 23.5\%@1.0 lit/ha + glyphosate 41\% SL @ 2.62 lit/ha. Among different herbicides, the higher yield per hectare $(32.31 \mathrm{t} / \mathrm{ha})$ and the lower weed index $(5.76 \%)$ were recorded with tank mix post-emergent application of oxyfluorfen 23.5\% @ 1.0 lit/ha + glyphosate 41\% SL @ 2.62 lit/ha. No phyto-toxicity symptoms viz. leaf tip/surface injury, wilting, vein clearing, necrosis, epinasty and/ or hyponasty were observed.
\end{abstract}

Keywords: Grape, herbicides, weed flora, weed index and phyto-toxicity symptoms

\section{Introduction}

Grape cultivation in one of the most remunerative farming enterprises in India. Grape (Vitis vinifera L.) is grown under a variety of soil and weather condition in different agro climatic zones namely, subtropical, hot tropical and mild tropical regions in India. The fruits are rich in sugar, particularly fructose, low caloric output, refreshing and easily digestible. It is one of the most ancient crops known to man. Grape cultivation is believed to have originated in Armenia near the Caspian Sea in Russia from where it seems to have spread westward to Europe and eastward to Iran and Afghanistan. Muslim invaders from Iran and Afghanistan during 1300 A.D. have introduced grapes to India. In India, the area under grape is estimated as 1, 37,000 ha with an annual production of 29, 51, 000 metric tonnes (Anon, 2018) ${ }^{[1]}$. Maharashtra is the leading grape growing state in the country with the highest area under cultivation (around 71.5 per cent of total area) and 80 per cent of country's production.

Studies have shown that full season competition due to unmanaged weeds could cause yield reductions by up to $37 \%$, cane weight by $68 \%$, number of cluster per vine by $28 \%$ and berry weight by $3 \%$ (Byrne and Howell, 1978) ${ }^{[5]}$. Weed menace is considered to be one of the major constraints in grape production next to nutrient management as the weeds have greater adaptability to adverse environment and greater potential for perpetuation when compared with cultivated plant species. Weeds compromise crop productivity through competition for plant resources including water, soil nutrients and light. In some instances, weeds harbor and vector plant pests and pathogens (Wisler and Norris 2005) ${ }^{[16]}$. In India, grapes cultivation is under different soil and cultural conditions. Weed flora in general, varies according to the climate and physico-chemical properties of the soil. Regardless of the agro-climate conditions, Parthenium (Parthenium hysterophorus Linn.), Hariyali (Cynodon dactylon (L.) and Nut grass (Cyperus rotundus L.) are common weeds in Indian vineyards, although as many as 378 weed species have been reported to have infested Karnataka 's cultivated lands (Krishna et al., 1980) [9]. Hand weeding though an effective process, is laborious, expensive, time-consuming and unsuitable for large grape vineyards. This necessitates the use of herbicides in developing countries such as India for proper and economically control of weeds in vineyards.
Corresponding Author: Assistant Professor, Department of Agronomy, College of Horticulture, Karnataka, India 
Herbicides have proven to be particularly useful for controlling weeds under the vines and can be drastically save on labor. However, Due to the sensitivity of the vine to certain herbicides, the growers must be careful in selecting and applying the appropriate herbicide at the appropriate rate.

\section{Material and methods}

A field experiment on grape (Vitis vinifera L.) $c v$. "2A Clone" was conducted at Main Horticulture Research and Extension Center (MHREC) University of Horticultural Sciences, Bagalkote after October pruning of 2019 to test the effect of various herbicides for controlling weeds in the vineyards under dry zone climate of north Karnataka. The experimental area comes under northern dry agro climatic zone of Karnataka (Zone-3) located at $16^{\circ} 10^{1}$ North latitude, $74^{\circ} 42^{1}$ East longitude with an altitude of 542 meters above the mean sea level. The trial was laid out in randomized complete block design (RCBD), having ten treatments with three replications. These vines were raised on Dog Ridge rootstock at distance of $3.0 \times 1.5 \mathrm{~m}$. Four vines were selected as unit plot. Treatment details are given below in Table 1. Among the different weeds the most common monocotyledonous weeds prevailed in the experimental field were Cynodon dactylon (L) Pers., Cyperus rotundus L., Digitaria sanguinalis (L) Scop., Panicum isachine L., Setaria sps while, common dicotyledonous weeds were Amarantus viridis Linn., Sonchrus arvensis L.,
Euphorbia hirta L., Parthenium hysterophorus Linn., Acalypa indica L., Physalis minima L., Withania somnifera L. and (Lactuca runcinata L.). In the each treated and untreated plots, a quadrat of $0.5 \mathrm{~m} \times 0.5 \mathrm{~m}$ was placed randomly and weeds were counted at different intervals after spraying, the weed count per square meter was then worked out. The average yield $\mathrm{t} / \mathrm{ha}$ was obtained by multiplying yield ( $\mathrm{kg} / \mathrm{vine}$ ) with total number of vines per hectare. Total soluble solids of the juice was determined by using a digital refractometer and juice $\mathrm{pH}$ was determined by using $\mathrm{pH}$ meter. The observation on phyto-toxicity viz. vine clearing, chlorosis, necrosis, wilting, scorching, hyponasty and epinasty of grape vine was recorded at $1,3,5,7$ and 10 days after application of herbicide on the basis of phyto-toxicity rating scale (PRS).

Weed index was calculated by using the following formulae given by (Gill and Vijayakumar, 1969) ${ }^{[7]}$.

$$
\begin{gathered}
\text { Yield obtained in weed free plot - Yield } \\
\text { obtained in treated plot }
\end{gathered}
$$$$
\text { WI }(\%)=\text {----------------- }
$$

Due to high degree of variation, data was subjected to squareroot transformation to make the analysis of variance valid as suggested by Gomez and Gomez (1984) ${ }^{[8]}$.

\begin{tabular}{|c|c|c|c|}
\hline $\begin{array}{l}\text { T. } \\
\text { No }\end{array}$ & Treatment & $\begin{array}{c}\text { Formulation } \\
\text { (L or kg/ha) }\end{array}$ & Remarks \\
\hline 1 & Oxyfluorfen $23.5 \%$ & 1.0 & Pre-emergent, sprayed direct on soil surface \\
\hline 2 & Diuron $80 \% \mathrm{WP}$ & 2.0 & Water Volume: 750 liters /ha \\
\hline 3 & Paraquat $24 \%$ SL & 3.0 & \multirow{6}{*}{$\begin{array}{c}\text { Post-emergent, sprayed at 3-4 leaf stage of } \\
\text { weeds } \\
\text { Water Volume: } 500 \text { liters /ha }\end{array}$} \\
\hline 4 & Glyphosate $41 \%$ SL & 2.62 & \\
\hline 5 & Oxyfluorfen 2.5\%@1.0 1/ha + Glyphosate 41\% SL (Ready Mix) & $1.0+2.62$ & \\
\hline 6 & Oxyfluorfen 23.5\% @ 1.0 1/ha + Glyphosate 41\% SL (Tank Mix) & $1.0+2.62$ & \\
\hline 7 & Diuron 80\% WP @ 2.0 kg/ha + Glyphosate 41\% SL (Tank Mix) & $2.0+2.62$ & \\
\hline 8 & Oxyfluorfen 23.5\% @ 1.0 1/ha plus Paraquat 24\% SL (Tank Mix) & $1.0+3.0$ & \\
\hline 9 & Hand weeding/ Weed free & & 2 weeks Interval \\
\hline 10 & Weedy check/ Control & & \\
\hline
\end{tabular}

Table 1: Treatment details

\section{Results and discussion}

\section{Effect of herbicides on weeds}

Herbicide treatments in grape vineyard significantly reduced the total number of weeds $/ \mathrm{m}^{2}$ compared to $\mathrm{T}_{10}$ - weedy check plot, Table 2. The results revealed that, total number of weeds $/ \mathrm{m}^{2}$ at 30 days after spraying among different herbicide treatments was lowest with $\mathrm{T}_{6^{-}}$tank mix post-emergent application of oxyfluorfen 23.5\% @ 1.0 1/ha + glyphosate $41 \%$ SL @ 2.62 1/ha $\left(4.67 / \mathrm{m}^{2}\right)$, which was significantly superior over all other treatments except $\mathrm{T}_{5}$ - ready mix postemergent application of oxyfluorfen $2.5 \%$ @ 1.0 1/ha + glyphosate $41 \%$ SL @ $2.621 / \mathrm{ha}\left(5.00 / \mathrm{m}^{2}\right)$ and $\mathrm{T}_{1^{-}}$preemergent application of oxyfluorfen 23.5\% @ 1.0 1/ha $\left(8.00 / \mathrm{m}^{2}\right)$.

At 60 days after spraying among different herbicide treatments, the lowest number of total weeds $/ \mathrm{m}^{2}\left(9.00 / \mathrm{m}^{2}\right)$ was recorded with $\mathrm{T}_{6^{-}}$tank mix post-emergent application of oxyfluorfen 23.5\%@1.0 1/ha + glyphosate 41\% SL @ 2.62 1/ha, which was significantly superior over all other treatments except $\mathrm{T}_{5}$ - ready mix post-emergent application of oxyfluorfen $2.5 \% @ 1.0$ 1/ha + glyphosate 41\% SL @ 2.62 1/ha $\left(10.67 / \mathrm{m}^{2}\right)$ and $\mathrm{T}_{1^{-}}$pre-emergent application of oxyfluorfen $23.5 \%$ @1.0 1/ha $\left(13.00 / \mathrm{m}^{2}\right)$. Similarly at 90 and 120 days after spraying of herbicides $\mathrm{T}_{6^{-}}$tank mix post- emergent application of oxyfluorfen 23.5\% @ 1.0 1/ha + glyphosate 41\% SL @ 2.62 1/ha recorded the lowest number of total weed $/ \mathrm{m}^{2}\left(16.00 / \mathrm{m}^{2}\right.$ and $23.00 / \mathrm{m}^{2}$, respectively), which was significantly superior over all other treatments except $\mathrm{T}_{1^{-}}$ pre-emergent application of oxyfluorfen 23.5\% @ 1.0 1/ha $\left(20.00 / \mathrm{m}^{2}\right.$ and $\left.8.67 / \mathrm{m}^{2}\right)$ and $\mathrm{T}_{5^{-}}$ready mix post-emergent application of oxyfluorfen $2.5 \%$ @ 1.0 1/ha + glyphosate $41 \%$ SL@ $2.621 /$ ha $\left(24.00 / \mathrm{m}^{2}\right.$ and $\left.30.67 / \mathrm{m}^{2}\right)$, respectively. The significantly reduction of total number of weeds were due that, glyphosate is more effective on broad leaved weeds particularly rhizomatous and deep-rooted perennial weeds, and oxyfluorfen which is known for its efficacy against all types of weeds. The studies are in confirmation with the earlier works by Patil et al. (2008) ${ }^{[11]}$, Bajwa (1990) ${ }^{[3]}$ and Bajwa et al. (1992) ${ }^{[4]}$.

Glyphosate's effectiveness after application may be attributed to its rapid action as a systemic herbicide that kills both the root and shooting system and causes the weeds to die within a week. "Similar results have also been reported by Yamdagni and Sharma (1992) ${ }^{[17]}$ and Muniyappa and Prathibha (1993) [10]. This success in controlling all kinds of weeds may be attributed to the three-month persistence of oxyfluorfen in the soil, which was effective for sprouting weeds. According to Challa (1984 and 1987) ${ }^{[6]}$ who reported that, Oxyfluorfen has 
been very successful in controlling both broad leaved and grassy weeds in mango stock nurseries and grape vine nurseries. Similarly, Aulakh (1999) ${ }^{[2]}$ also indicated that, with the application of oxyfluorfen in Perlette grape cuttings, the weed population was significantly decreased in accordance with hand weeding but was on par with diuron and atrazine.

\section{Yield and Quality as influenced by different herbicides}

The data showed that, higher yield per hectare (34.29 t/ha) was recorded in $\mathrm{T}_{9^{-}}$weed free check. Among the different herbicide treatments the maximum yield per hectare of 32.31 $\mathrm{t} / \mathrm{ha}$ ) was obtained in $\mathrm{T}_{6}$ - tank mix post-emergent application of oxyfluorfen 23.5\%@1.0 1/ha + glyphosate 41\% SL @ $2.62 \mathrm{l} / \mathrm{ha}$, which was significantly superior over $\mathrm{T}_{7-}$ tank mix post-emergent application of diuron 80\% WP @ $2.0 \mathrm{~kg} / \mathrm{ha}+$ glyphosate $41 \%$ SL @ 2.62 1/ha (26.07 t/ha), T $4_{4}$ postemergent application of glyphosate $41 \%$ SL @ 2.62 1/ha (26.83 t/ha), $\mathrm{T}_{3^{-}}$post-emergent application of paraquat $24 \%$ SL @ 3.0 1/ha (26.87 t/ha), $\mathrm{T}_{8^{-}}$tank mix post-emergent application of oxyfluorfen $23.5 \%$ @ 1.0 1/ha + paraquat $24 \%$ SL @ $3.01 /$ ha $(27.26 \mathrm{t} / \mathrm{ha})$ and $\mathrm{T}_{2^{-}}$pre-emergent application of diuron $80 \%$ WP @ $2.0 \mathrm{~kg} / \mathrm{ha}(27.88 \mathrm{t} / \mathrm{ha})$. However, it was on par with those of $\mathrm{T}_{5}$ - ready mix post-emergent application of oxyfluorfen 2.5\%@1.0 1/ha + glyphosate 41\% SL @ 2.62 1/ha (30.41 t/ha) and $\mathrm{T}_{1^{-}}$pre-emergent application of oxyfluorfen 23.5\% @ 1.0 1/ha (28.90 t/ha) and the lower yield per hectare of $22.54 \mathrm{t} /$ ha was recorded with $\mathrm{T}_{10}$ - weedy check. Higher yield per hectare was due to high bunch weight with optimum number of bunches per vine, which led to increased yield per vine and finally resulted in the increased yield per hectare. Low weed intensity could have benefited the vines to consume sufficient nutrients and moisture, which in turn put for the better canopy and helped the vine to produce more number of bunches per vine. Yield per hectare is positively correlated with number of bunch per vine, bunch weight and yield per vine (Table 3 ).

The results are in line with those of Patil et al. (2008) ${ }^{[11]}$ and Ramteke et al. (2012) ${ }^{[13]}$ who reported that high yield per hectare of grape is because of more weight and number of bunched per vine. Prathiba et al. (1995) ${ }^{[12]}$ also reported that, herbicide treatments recorded more yield in grape because of more number of bunches per vine.

The data revealed on total soluble solids (TSS) and juice $\mathrm{pH}$ in grape berries was not differed significantly with different weed control treatments. The data recorded on total soluble solids was at the range of 19.63 to $20.11{ }^{\circ}$ Brix, and juice $\mathrm{pH}$ was 3.28 to 3.34 (Table 3 ).

\section{Weed index $(\%)$}

The lowest weed index $(0.00 \%)$ was noticed in weed free check $\left(\mathrm{T}_{9}\right)$, while the highest weed index $(34.26 \%)$ was recorded in weedy check $\left(\mathrm{T}_{10}\right)$. Among different herbicide treatments, $\mathrm{T}_{6^{-}}$tank mix post-emergent application of oxyfluorfen $23.5 \%$ @ 1.0 1/ha + glyphosate $41 \%$ SL @ 2.62 1/ha obtained the lowest weed index $(5.76 \%)$, which was significantly superior over all other treatments except $\mathrm{T}_{5^{-}}$ ready mix post-emergent application of oxyfluorfen $2.5 \%$ @ 1.0 1/ha + glyphosate $41 \%$ SL @ 2.62 1/ha (11.25\%).

In present study unmanaged weed caused $34.26 \%$ reduction of highest yield (34.29 $\mathrm{t} / \mathrm{ha}$ ) recorded in weed free check $\left(\mathrm{T}_{9}\right)$, while among different herbicide treatment $\mathrm{T}_{6^{-}}$tank mix postemergent application of oxyfluorfen $23.5 \%$ @ 1.0 1/ha + glyphosate 41\% SL @ 2.62 1/ha caused lower yield reduction of $5.76 \%$, and its due to well control of weeds in vineyard with combination of both pre and post-emergent application of oxyfluorfen and glyphosate which have effectively controlled broad leaved, grassy and total weeds in vineyard.

According to Patil et al. (2008) [11] who reported that, uncontrolled weed during two year of investigation caused $47.72 \%$ reduction in Thompson Seedless grape yield and Ramteke et al. (2012) ${ }^{[13]}$ and (2013) ${ }^{[14]}$ also stated that, unmanaged weed during the crop production period resulted in reduction of $36.05 \%$ and $45.66 \%$ yield, respectively. Susaj et al., (2013) ${ }^{[15]}$ also reported that unmanaged weeds caused $34.14 \%$ yield in wine grapes.

\section{Phyto-toxicity symptoms of herbicides on grape vines}

No phyto-toxicity symptoms viz. leaf tip/surface injury, wilting, vein clearing, necrosis, epinasty and/ or hyponasty were observed at 1, 3, 5, 7 and 10 after spraying of herbicides treatments.

\section{Conclusion}

In the present research work, it could be inferred that, Tank mix post-emergent application of oxyfluorfen 23.5\%@1.0 1/ha + glyphosate 41\% SL @ 2.62 1/ha $\left(\mathrm{T}_{6}\right)$ was the best treatment with respect to lower weed number $/ \mathrm{m}^{2}$, higher yield $(\mathrm{t} / \mathrm{ha})$ and lower weed index (\%) in grape. No phyto-toxicity symptoms viz., leaf tip/surface injury, wilting, vein clearing, necrosis, epinasty and/ or hyponasty were observed during the experiment.

Table 2: Weed density per $\mathrm{m}^{2}$ as influenced by herbicides at different interval in grape vineyard $c v$. 2A Clone.

\begin{tabular}{|c|c|c|c|c|c|c|}
\hline \multirow{2}{*}{ S. No. } & \multirow{2}{*}{ Treatment } & \multirow{2}{*}{\begin{tabular}{|c|} 
Formulation \\
(L or kg/ha) \\
\end{tabular}} & \multicolumn{4}{|c|}{ Total number of weeds $/ \mathrm{m}^{2}$} \\
\hline & & & 30 DAP & 60 DAP & 90 DAP & 120 DAP \\
\hline 1 & Oxyfluorfen $23.5 \%$ & \begin{tabular}{|l|}
1.0 \\
\end{tabular} & $8.00(2.99) *$ & $13.00(3.73)$ & $20.00(4.58)$ & $24.67(4.97)$ \\
\hline 2 & Diuron $80 \% \mathrm{WP}$ & 2.0 & $12.00(3.52)$ & $19.67(4.48)$ & $32.33(5.69)$ & $44.67(6.73)$ \\
\hline 3 & Paraquat 24 SL & 3.0 & $20.67(4.62)$ & $26.67(5.24)$ & $38.33(6.24)$ & $52.33(7.28)$ \\
\hline 4 & Glyphosate $41 \%$ SL & 2.62 & $16.67(4.17)$ & $25.67(5.13)$ & $36.67(6.13)$ & $50.33(7.15)$ \\
\hline 5 & Oxyfluorfen $2.5 \%$ + Glyphosate $41 \%$ (RM) & $1.0+2.62$ & $5.00(2.44)$ & $10.67(3.41)$ & $24.00(4.97)$ & $30.67(5.57)$ \\
\hline 6 & Oxyfluorfen $23.5 \%$ + Glyphosate $41 \%$ (TM) & $1.0+2.62$ & $4.67(2.37)$ & $9.00(3.15)$ & $16.00(4.12)$ & $23.00(4.88)$ \\
\hline 7 & Diuron $80 \%$ WP + Glyphosate $41 \%$ (TM) & $2.0+2.62$ & $23.67(4.85)$ & $30.67(5.55)$ & $40.33(6.38)$ & $58.67(7.72)$ \\
\hline 8 & Oxyfluorfen $23.5 \%$ + Paraquat $24 \%$ SL (TM) & $1.0+3.0$ & $15.00(3.58)$ & $19.67(4.27)$ & $33.33(5.66)$ & $45.67(6.66)$ \\
\hline 9 & Hand Weeding/ Weed free & - & $0.00(1.00)$ & $0.00(1.00)$ & $0.00(1.00)$ & $0.00(1.00)$ \\
\hline 10 & Weedy check/ control & - & $108.33(10.41)$ & $133.67(11.59)$ & $161.00(12.71)$ & $193.00(13.91)$ \\
\hline \multicolumn{3}{|c|}{ S.Em \pm} & 0.31 & 0.35 & \begin{tabular}{l|l}
0.31 \\
\end{tabular} & 0.35 \\
\hline \multicolumn{3}{|c|}{ C.D. at $5 \%$} & 0.91 & 1.03 & 0.91 & 1.03 \\
\hline
\end{tabular}

$\mathrm{RM}=$ Ready Mix, TM= Tank Mix, DAP= Days after spraying

* Figures in the parentheses are $\sqrt{ } \mathrm{x}+1$ values. 
Table 3: Yield and quality parameters of grape $c v$. 2A Clone as influenced by different herbicides.

\begin{tabular}{|c|c|c|c|c|c|}
\hline S. No. & Treatment & $\begin{array}{c}\text { Formulation } \\
\text { (L or kg/ha) } \\
\end{array}$ & Yield (t/ha) & Total soluble solids ( ${ }^{\circ}$ Brix) & Juice pH \\
\hline 1 & Oxyfluorfen $23.5 \%$ & 1.0 & 28.90 & 19.68 & 3.31 \\
\hline 2 & Diuron $80 \% \mathrm{WP}$ & 2.0 & 27.88 & 19.92 & 3.34 \\
\hline 3 & Paraquat 24 SL & 3.0 & 26.87 & 19.63 & 3.30 \\
\hline 4 & Glyphosate $41 \%$ SL & 2.62 & 26.83 & 20.00 & 3.32 \\
\hline 5 & Oxyfluorfen $2.5 \%$ + Glyphosate $41 \%$ (RM) & $1.0+2.62$ & 30.41 & 19.92 & 3.28 \\
\hline 6 & Oxyfluorfen $23.5 \%$ + Glyphosate $41 \%$ (TM) & $1.0+2.62$ & 32.31 & 19.78 & 3.30 \\
\hline 7 & Diuron $80 \%$ WP + Glyphosate $41 \%$ (TM) & $2.0+2.62$ & 26.07 & 19.87 & 3.32 \\
\hline 8 & Oxyfluorfen $23.5 \%$ + Paraquat $24 \%$ SL (TM) & $1.0+3.0$ & 27.26 & 19.75 & 3.34 \\
\hline 9 & Hand Weeding/ Weed free & - & 34.29 & 19.63 & 3.33 \\
\hline 10 & Weedy check/ control & - & 22.54 & 20.11 & 3.29 \\
\hline \multicolumn{3}{|c|}{ S.Em \pm} & 1.20 & 0.17 & 0.02 \\
\hline \multicolumn{3}{|c|}{ C.D. at $5 \%$} & 3.54 & NS & NS \\
\hline
\end{tabular}

RM= Ready Mix, TM= Tank Mix, NS= Non Significant

Table 4: Weed index in grape $c v$. 2A Clone as influenced by different herbicides.

\begin{tabular}{|c|c|c|c|}
\hline \multirow{2}{*}{ S. No. } & Treatment & Formulation & \multirow{2}{*}{ Weed Index (\%) } \\
\cline { 3 - 3 } & & (L or kg/ha) & \\
\hline 1 & Oxyfluorfen 23.5\% & 1.0 & $15.69(4.06)^{*}$ \\
\hline 2 & Diuron 80\% WP & 2.0 & $18.70(4.44)$ \\
\hline 3 & Paraquat 24\% SL & 3.0 & $21.60(4.66)$ \\
\hline 4 & Glyphosate 41\% SL & 2.62 & $21.73(4.75)$ \\
\hline 5 & Oxyfluorfen 2.5\% + Glyphosate 41\% (RM) & $1.0+2.62$ & $11.25(3.17)$ \\
\hline 6 & Oxyfluorfen 23.5\% + Glyphosate 41\% (TM) & $1.0+2.62$ & $5.76(2.57)$ \\
\hline 7 & Diuron 80\% WP + Glyphosate 41\% (TM) & $2.0+2.62$ & $23.96(4.99)$ \\
\hline 8 & Oxyfluorfen 23.5\% + Paraquat 24\% SL (TM) & $1.0+3.0$ & $20.49(4.63)$ \\
\hline 9 & Hand Weeding/Weed free & - & $0.00(1.00)$ \\
\hline 10 & Weedy check/ control & - & $34.26(5.93)$ \\
\hline \multicolumn{3}{|c|}{ S.Em \pm} & 0.30 \\
\hline
\end{tabular}

RM= Ready Mix TM= Tank Mix

* Figures in the parentheses are $\sqrt{ } \mathrm{x}+1$ values.

\section{References}

1. Anonymous. Indian horticulture database. National horticulture board, Gurgaon, Haryana, India, 2018.

2. Aulakh PS. Chemical weed control in Perlette grape cuttings. Progr. Hort. 1999; 31:68-69.

3. Bajwa GS. Weed management in vineyards. Paper presented in the national seminar cum workshop on grapes for northwest plains held at Punjab agricultural university, Ludhiana, 1990, 65.

4. Bajwa GS, Minhas PPS, Brar SS, Bal JS. Effect of various herbicides on weed control in pear orchards. Indian J Hort. 1992; 49(4):313-317.

5. Byrne ME, Howell GS. Initial response of Baco noir grapevine to pruning severity, sucker removal, and weed control. American. J Enol. Viti. 1978; 29:192-198.

6. Challa P. Chemical weed control in mango rootstock nurseries. Tropical Pest Mngt. 1984; 30:466-67.

7. Gill GS, Vijaykumar. "Weed Index" a new method for reporting weed control trails. Indian J Agron. 1969; 16:96-98.

8. Gomez KA, Gomez AA. Statistical Procedures for Agricultural Research. International Rice Research Institute, Wiley-Int. Sci. Publi., New York, USA, 1984, 680.

9. Krishna SKS, Boraiah G, Govindu HC, Khakleel TF. Weeds of Karnataka, UAS Text book Series No.2. University of agricultural sciences, Bangalore, 1980, 359.

10. Muniyappa TV, Prathibha NC. Effect of herbicides on the control of Oxalis latifolia in grape garden. Proceedings of International Symposium Indian Soc. Weed Sci., Hisar. 1993; III:275-276.
11. Patil DR, Sulikeri GS, Patil HB. Studies on the weed management practices in Thomson seedless grape vineyard. Int. Symp. Grape production. \& proc. 2008, 321-326.

12. Prathibha NC, Muniyappa TV, Murthy BG. Studies on chemical weed control of Oxalis latifolia on growth, yield and quality of grapes. J Maharashtra Agril. Univs. 1995; 20(2):202-205.

13. Ramteke SD, Rajurkar AB, Bhange MA, Kor RJ. Chemical management of broad leaved weeds in grapes. Indian J weed sci. 2012; 44(3):196-199.

14. Ramteke SD, Bhange MA, Somkuwar RG, Kor RJ. Efficiency of weedicide (UPH 707) to control complex weed flora in Thompson seedless grape vineyard. Progr. Hort., 2013; 45(2):259-264.

15. Susaj L, Susaj E, Belegu M, Mustafa S, Dervishi B, Ferraj B. Effects of different weed management practices on production and quality of wine grape cultivar Kallmet in North-Western Albania. J Food, Agri. \& Env. 2013; 11(1):379-382.

16. Wisler GC, Norris RF. Interactions between weeds and cultivated plants as related to management of plant pathogens. Symp. Weed Sci. 2005; 53:914-917.

17. Yamdagni R, Sharma S. Weed control and moisture conservation technology for grapes in North India. Drakshavritta Souvenir, 1992, 45-60. 